\title{
A COHORT ANALYSIS OF THE COLLEGE PREMIUM IN MEXICO*
}

\section{Francisco Benita**}

\begin{abstract}
This paper provides the first empirical evidence for Mexico about relative wage differences between college-educated and high-school-educated workers across five-year age groups. Rotating panel surveys are used to implement an imperfect substitution model for similar male workers between different age groups and between the two education groups. For the period 2005-2012, the results suggest a partial elasticity of substitution of 1.7 for college- and high-school-educated workers and a partial elasticity of substitution of about 3 across age groups. Remarkably, the wage gap between younger and older workers with the same education level increased after the economic crisis of 2008.
\end{abstract}

JEL classification: J21, J31, C33

Keywords: Wage differentials, cohort effects, rotating panel, elasticity of substitution, Mexico

\section{INTRODUCTION}

Human capital theory proposes that education improves labor force productivity by imparting useful knowledge and skills. Over the past 40 years, many studies have examined rising rates of returns to education. Most of these studies have shown that schooling is a key factor in explaining wage gaps among individuals. On the other hand, in developed and some developing countries, average schooling has been increasing steadily over time, resulting in an expanded rise in salaries and a substantial narrowing of the wage gap. A second phenomenon of interest is the aging of the population, mainly occurring in developed countries, and more recently in some developing countries. In these countries there will be a higher absolute number of elderly people, who will make up a larger share of the population and have longer healthy life expectancies, and there will be a relatively lower number of working-age people.

The Mexican case is particularly interesting in this context for several reasons. First, Mexico's labor structure has undergone various political,

\footnotetext{
* I would like to thank the editor and two anonymous reviewers for their valuable comments and suggestions.

** Department of Systems \& Industrial Engineering, ITESM (Tec de Monterrey), Campus Monterrey, Av. Eugenio Garza Sada Sur 2401, Monterrey, NL, 64849, Mexico. Email: francisco_benita@hotmail.com.
} 
economic, and demographic changes, affecting both increases in schooling and growth in the elderly population over the past three decades. Second, wage inequality trends have been substantially different than those observed in other developing countries (Tello and Ramos, 2012). According to the Mexican Population and Housing Census, the average number of years of education in the labor force has strongly increased, from 3.4 years in 1970 to 7.5 years in 2000, and this growth trend has continued, reaching 8.8 years of education in 2010. In addition, the country has seen an increase in the average age, from 22 years in 2000 to 26.7 years in 2010. Like many parts of the world, Mexico has witnessed a growth in the proportion of its elderly population compared to all other age groups.

Both demographic (aging) and economic (schooling) effects imply relative changes in the labor supply, with possible strong variations in returns to education between age groups. Growth in the pool of young, highly educated workers has resulted in an increase in the country's labor supply. Likewise, it is possible that the gap in average earnings between less-educated and highly educated workers narrows if labor demand is unchanged. This long-term phenomenon raises several questions about the future development of wage and employment structures by age groups. The issue is relevant for different economic topics, such as social security actuarial calculations, increasing wage inequality, age-related government transfers, pensions, health care, and labor market reforms.

There is a large literature on education's effect on earnings in Mexico, focused on factors that largely explain the wage gap between highly educated and less-educated workers resulting from changes in labor demand (e.g., Cragg and Epelbaum, 1996, Hanson and Harrison, 1999, Hernández, 2000, Cañonero and Werner 2002, and Chiquiar, 2008, among others). However, there is no empirical evidence on this effect according to different age groups of workers. Hence, the objective of this paper is to test whether the increase over the last decade in the number of male college graduates has led to downward pressure on the college wage premium. Furthermore, it seeks to determine whether the increase in relative supplies could possibly lead to a narrowing of the wage gap between college-educated male workers and male workers who possess only a high school diploma.

Because female labor-market participation in developing countries is the result of an underlying choice process based on utility maximization (Becker, 1965) and the modeling requires appropriate statistical 
methods to control self-selection bias, this study is limited to male workers. Following the econometric methodology proposed by Card and Lemieux (2001) and using rotating panel data from 2005 to 2012, I present the partial elasticity of substitution between college and high school workers and between different age groups. Since empirical evidence suggests that younger workers cannot easily replace older workers (Rones, 1983, Hairault et al., 2007, Bia et al., 2009, or Kalwij et al., 2010), I use an imperfect substitution model for similar male workers between different age groups. In addition, I estimate not only the elasticity of substitution between younger and older male workers but also the elasticity of substitution of workers with a college degree and those with only a high school diploma. In developing countries such as Mexico, estimation of the education wage premium by age groups and its elasticity is important for determining the allocation of public spending on educational policies, which should be oriented toward educational improvement and raising worker productivity.

The model represents a competitive equilibrium from the firm side, where entrepreneurs select the amount of labor required to maximize profits. The estimation results indicate that there is a large elasticity substitution (about 3) between male workers with different levels of education, which could be interpreted to mean that college- and high-school-educated workers are considered easily interchangeable by employers. Furthermore, the small value of the estimated parameteraround 1.7-between the two education groups suggests that young and old workers are considered different by employers and therefore they are far from perfect substitutes. This result is very important because it suggests that in the current Mexican labor market it is easier to substitute skilled workers with unskilled workers than to replace older workers with a younger labor force.

The remainder of this paper is organized as follows. Section 2 provides a review of the related literature, while Section 3 outlines the theoretical framework. Section 4 presents a characterization of the estimation strategy and the dataset description. The results and some discussion are presented in Section 5, while Section 6 contains concluding remarks.

\section{Literature REVIEW}

Changes in labor supply and demand have no specific effect on relative wages, particularly between skilled and unskilled workers. Katz and Murphy's (1992) seminal work on movements in the college 
wage premium from 1963 to 1987 in the United States concludes that the premium appears to be strongly related to fluctuations in the growth rate of the supply of college graduates. Understanding these relationships is very important for economic development since labor supply affects the environment in which the labor market functions.

In general, we note that the wage gap in Mexico has been widely discussed, especially during the 1980s and the first half of the 1990s. It is generally agreed that the wage gap between college-educated male workers and those with only a high school diploma is due to changes in labor demand, which are explained using two different approaches: trade liberalization and technological change.

In relation to trade liberalization, changes have occurred as a result of employers' strategies to reward the qualifications of their employees in order to increase their international competitiveness. In regard to technological change, reduction of trade barriers and the rise in foreign direct investment have led to increased use of technology, which in turn has driven demand for skilled workers to complement the technology. As a result, the relative productivity of skilled workers, mainly those with college and advanced degrees, has been increased by such technological changes.

Following the focus on trade liberalization, in the view of Zepeda and Ghiara (1999) the trade reforms that took place in Mexico between 1986 and 1990 were accompanied by important wage gaps between skilled and unskilled workers. Applying a quantile regression to estimate the conditional distribution of income, Zamudio (2001) finds that between 1984 and 1996 the distribution of income depends to a large extent on education. Cañonero and Werner (2002) study the widening of wage differentials for skilled and unskilled workers after Mexico's entry into the General Agreement on Tariffs and Trade (GATT) and find that the average relative wage of an unskilled worker had decreased by more than $20 \%$ by the end of 1990 . In a similar context, Hanson (2003) focuses on policy reforms initiated during the 1990s, finding a significant rise in demand for skilled workers in the country and concluding that the policies reduced profits in industries that paid their workers high wages prior to the reform and raised the premium paid to workers in states along the U.S. border. Airola and Juhn (2008) argue that trade liberalization per se did not widen wage differentials in the region. Finally, in the view of Chiquiar (2008), in the period following implementation of the North 
American Free Trade Agreement (NAFTA), the wage premium for high-skilled workers increased in what he calls the "second stage of globalization in Mexico."

Following the second approach, Hanson and Harrison (1995, 1999) suggest that the rising wage gap during the 1980s was associated with changes internal to industries and even internal to plants. Cragg and Epelbaum (1996) report significant changes in returns to specific occupations, in particular professionals and managers, but they believe that rising inequality in the early 1990s is largely due to trade liberalization reforms. In a similar study, Meza (1999) concludes that if the skills premium had not risen over the 1988-1993 period, the wage distribution would be improved. Finally, Hernández (2000) points out that technological changes associated with trade liberalization have promoted an incipient territorial decentralization focused on the U.S. border and the periphery of Mexico City.

Among more recent studies, Huesca (2004) finds that workers with high school and college education show higher returns to schooling because of an upward trend in demand for skilled workers. Lopez (2006) notes that the Mexican population is becoming more educated. The author shows how years of schooling have increasing over the 19601990 period, growing from 2.76 years in 1960 to 6.72 years in 1990, a difference of nearly four years. According to Ampudia (2007), trade liberalization and international markets increased demand for skilled labor, which in turn generated higher education wage premiums. For workers with a college degree, the education premium has been shown to be cyclical in times of recession.

Although there is extensive literature documenting the role of educational level on the wage gap in Mexico, most previous studies have focused on average returns to schooling rather than differences by age or cohort. While the rise in the average wage gap between college and high school workers has been briefly documented, the fact that the increases have varied among different age groups is not as well understood.

These studies analyze the evolution of returns to schooling under the assumption that different age groups with the same level of education are perfect substitutes in production processes. This assumption implies that the aggregate supply of each type of education can be obtained by simply adding the total number of workers in each education category, such that all education-related wage differentials 
in the labor market in any given year are proportional to the average college-high school wage gap that year.

An analysis of the evolution of wage differentials by age groups was presented for the first time in Card and Lemieux (2001). The authors extend the model proposed by Katz and Murphy (1992) in order to allow imperfect substitution between workers of different ages for the U.S., the United Kingdom, and Canada. In the study, the authors point out that shifts in the college-high school wage gap for younger men in the U.S. reflect changes in the relative supply of highly educated workers across age groups. In their estimation of the elasticity of substitution of age groups with the same education level, they find elasticity close to 5 between different age groups in the U.S., while the elasticity of substitution between college graduates and high school graduates ranges from 1.1 to 2.5 , with similar results for both the U.K. and Canada.

Roger and Wasmer (2009) describe the importance of controlling for age and skill heterogeneity to explain labor productivity. Within this framework, some recent studies have continued the line of imperfect substitution of workers between different age groups. Ferreira (2004) tests the existence of a causal relationship between the evolution of the college-educated labor supply and the behavior of the college premium in Brazil by decomposing the relative supply of college-educated workers into two components: an age-specific component and a cohort-specific component. The author's main results suggest that the parameter for elasticity of substitution between different age groups is similar to the U.S., while the elasticity of substitution between two education groups is less than 2. Some implications of this result are outlined in Prskawetz et al. (2012), who introduce a model of optimal education policy at the macro level allowing for heterogeneity of the workforce with respect to its age and skills. Their estimations suggest that the relationship between the elasticity of substitution of labor across age groups plays a crucial role in the way demographic changes affect the optimal educational policy.

\section{BACKGROUND}

This work follows the two-step estimation method introduced by Card and Lemieux (2001). The theoretical model has a production function that uses labor as the sole input. In this simple model, the input can be skilled (college graduates) or unskilled (high school graduates) 
combined under a CES technology. The aggregate output depends on two CES sub-aggregates of high school and college workers:

$$
\begin{aligned}
& H_{t}=\left[\sum_{j}\left(\beta_{j t} H_{j t}^{\eta}\right)\right]^{1 / \eta}, \\
& C_{t}=\left[\sum_{j}\left(\alpha_{j t} C_{j t}^{\eta}\right)\right]^{1 / \eta},
\end{aligned}
$$

where $H_{t}$ and $C_{t}$ are the total supply of high school and college labor in period $t$, and $\eta \in(-\infty, 1]$ is a function of the partial elasticity of substitution, $\sigma_{A}$, between different age groups $j$ with the same level of education $\left(\eta=1-1 / \sigma_{A}\right)$. The $\alpha_{j}$ and $\beta_{j}$ coefficients are relative efficiency parameters that vary over time. Perfect substitutability across age groups necessarily implies that $\eta=1$. Therefore, total college or high school labor input is simply a weighted sum of the quantity of labor supplied by each group. In this work, the total supply of each type of work in each year is measured as the sum of the average weekly hours worked by members of the different education categories.

The model assumes an aggregate CES production function $y_{t}=\left(\theta_{c t} C_{t}^{\rho}+\theta_{h t} H_{t}^{\rho}\right)^{1 / \rho}$, where $y_{t}$ is the total output in period $t$, and $\rho \in(-\infty, 1]$ is a function of the elasticity of substitution $\sigma_{\mathrm{E}}$ between the two education groups $\left(\rho=1-1 / \sigma_{E}\right) \cdot \theta_{c t}$ and $\theta_{h t}$ are college and high-school productivity terms.

Under this specification, the marginal product of labor for a given age-education group depends on both the group's own supply of labor and the aggregate supply of labor in its education category. Formally, we have the following:

$$
\frac{\partial \mathrm{y}_{\mathrm{t}}}{\partial \mathrm{H}_{j t}}=\frac{\partial \mathrm{y}_{\mathrm{t}}}{\partial \mathrm{H}_{t}} \frac{\partial \mathrm{H}_{t}}{\partial \mathrm{H}_{j t}}=\theta_{h t} H_{t}^{\rho-1} \Psi_{t} \beta_{j t} H_{j t}^{\eta-1} H_{t}^{1-\eta}=\theta_{h t} H_{t}^{\rho-\eta} \Psi_{t} \beta_{j t} H_{j t}^{\eta-1}
$$

where $\Psi_{t}=\left(\theta_{c t} C_{t}^{\rho}+\theta_{h t} H_{t}^{\rho}\right)^{1 / \rho-1}$. Similarly, the marginal product of college workers in age group $j$ is $\partial y_{t} / \partial C_{j t}=\theta_{c t} C_{t}^{\rho-\eta} \Psi_{t} \alpha_{j t} C_{j t}^{\eta-1}$. Additionally, efficient utilization of different skill groups requires that relative wages are equal to relative marginal products: 


$$
\begin{aligned}
& \ln \left(w_{j t}^{H}\right)=\ln \left(\frac{\partial \mathrm{y}_{\mathrm{t}}}{\partial \mathrm{H}_{j t}}\right)=\ln \left(\theta_{h t} H_{t}^{\rho-\eta} \Psi_{t}\right)+\ln \left(\beta_{j t}\right)-\frac{1}{\sigma_{A}} \ln \left(H_{j t}\right) \\
& \ln \left(w_{j t}^{C}\right)=\ln \left(\frac{\partial \mathrm{y}_{\mathrm{t}}}{\partial C_{j t}}\right)=\ln \left(\theta_{c t} C_{t}^{\rho-\eta} \Psi_{t}\right)+\ln \left(\alpha_{j t}\right)-\frac{1}{\sigma_{A}} \ln \left(C_{j t}\right)
\end{aligned}
$$

From equations (4) and (5) it is possible to infer that the ratio of the wage rate of skilled workers in age group $j, w_{j t}^{C}$, to the wage rate of unskilled workers in the same age group, $w_{j t}^{H}$, satisfies:

$$
\ln \left(\frac{w_{j t}^{C}}{w_{j t}^{H}}\right)=\ln \left(\frac{\theta_{c t}}{\theta_{h t}}\right)+\ln \left(\frac{\alpha_{j t}}{\beta_{j t}}\right)+\left(\frac{1}{\sigma_{A}}-\frac{1}{\sigma_{E}}\right) \ln \left(\frac{C_{t}}{H_{t}}\right)-\frac{1}{\sigma_{A}} \ln \left(\frac{C_{j t}}{H_{j t}}\right)
$$

If relative employment ratios are taken as exogenous ${ }^{1}$, Equation (6) leads to a simple model for the observed college-high school wage gap in age group $j$ in period $t$ :

$$
\begin{aligned}
r_{j t} \equiv \ln \left(\frac{w_{j t}^{C}}{w_{j t}^{H}}\right)= & \ln \left(\frac{\theta_{c t}}{\theta_{h t}}\right)+\ln \left(\frac{\alpha_{j t}}{\beta_{j t}}\right)+\left(\frac{1}{\sigma_{A}}-\frac{1}{\sigma_{E}}\right) \ln \left(\frac{C_{t}}{H_{t}}\right) \\
& -\frac{1}{\sigma_{A}} \ln \left(\frac{C_{j t}}{H_{j t}}\right)+e_{j t}
\end{aligned}
$$

where $e_{j t}$ is the sampling variation in the measured gap and/or any other sources of variation in age-specific wage premiums.

The model represents a competitive equilibrium from the firm side, where entrepreneurs choose the amount of labor required to maximize profits. The equilibrium wage for the perfectly competitive market industry is computed by allowing imperfect substitution between workers of different ages.

As a result, the model specification represents a firm's production equilibrium. General equilibrium analysis deals explicitly with the

1. Total supply of high school and college labor in each period can be varied exogenously as a part of a scenario, e.g., simulating the effects of increasing participation of certain population groups. However, they do not respond endogenously to variations in other parameters such as the productivity or wage rate of college workers in each age group. In the case of Mexico, due to the effects of GATT and NAFTA on the economy, this can be assumed since input prices and technology can be more closely linked to tariff changes (Robertson, 2004). 
interdependence of households and firms as mediated by markets. With only one production factor it is particularly easy to illustrate production equilibrium. However, the model could be extended by adding other inputs such as capital. Also, within the problem statement it must be clear that the results are valid only in a perfectly competitive equilibrium scenario. Therefore, the model is not applicable to imperfect markets with monopoly or oligopoly labor demand (e.g., monopsony or oligopsony). Finally, Equation (7) becomes the equation to estimate. Note that the assumption of employment ratios as exogenous becomes essential for the results; otherwise, the weighted least squares of elasticity of substitution will have a positive basis.

\section{Estimation}

The empirical analysis is based on data extracted from the National Survey of Occupation and Employment (ENOE). These datasets are collected by the National Institute of Statistics and Geography of Mexico (INEGI) and are the basis for official employment statistics. The datasets are based on household surveys conducted on a quarterly basis, the main objective of which are to obtain information about demographic and economic characteristics of employment. The surveys are designed as panel data with overlapping blocks of observations that are renewed after being followed up over five consecutive quarters. This data is representative of the whole country, each of the 32 states, and urban and rural areas.

I analyze datasets from the first quarter of 2005 through the fourth quarter of 2012. These rotating panel data are used to derive labor market conditions for male workers ages 25-59 with either a high school diploma or a college degree. In addition, an important difference from previous studies is that I consider full-time workers (those working 48 hours or more per week) as well as part-time workers (those working between 48 and 96 hours per week).

For reasons related to analysis and interpretation, the strategy consists of estimating panels by following the individuals from the first through the fourth quarter of each year. This technique allows the estimation of robust coefficients, increasing the degrees of freedom and reducing collinearity among the explanatory variables. In general, panel data sets possess major advantages over conventional cross-sectional data sets. The data set in question consists of eight panels, each one made 
up of individuals who are interviewed in each of the four quarters of the year. The top and bottom $1 \%$ of the log real hourly wage, using 2010 as the base year, were dropped in order to avoid atypical values.

For a general overview of the effect of a college education on wages, I first estimate the college wage premium for each year $t$ with no distinctions between age groups, formally:

$$
\ln \left(w_{i q}\right)=\zeta_{0}+X_{i q}^{\prime} \zeta+v_{i q}
$$

where $w_{i q}$ contains the hourly wage of individual $i$ in quarter $q$, $q \in\{1,2,3,4\}$. $\zeta$ denotes the coefficient vector, matrix $X$ contains the regressors used to explain the dependent variable, and $v$ is a residual assumed to be $N\left(0, \sigma^{2}\right)$. Because schooling cannot change in each quarter, $v_{i q}=u_{i}+\mu_{i q}$ and the model becomes a generalized least squares $^{2}$. The regressor matrix $X$ contains information about age and its quadratic, a married category dummy variable, six economic activity dummies, five regional dummies, and a dummy variable for college degree. The proposed model specification is based on previous studies of Mexico described in Section 2. Although Equation (8) is not directly related to the estimation of Equation (7), it is a useful first approach to understanding the college premium. The assumption behind Equation (8) is that different age groups with the same level of education (college or high school) are perfect substitutes in production.

However, in order to capture the college wage premium within age groups, for each year $t$ I estimate separate regressions for each fiveyear age group, $j$ :

$$
\ln \left(w_{j q}\right)=\gamma_{0}+X_{j q}^{\prime} \gamma+\varepsilon_{j q}
$$

In Equation (9), the college degree dummy variable contained in matrix $X$ measures the college wage premium by five-year age groups. Secondly, we compute Equation (7) using the estimated college premium from Equation (9), but there is a problem because the aggregate supplies of the two education groups depend on the elasticity of substitution across

2. The critical assumption when using random effects is that regressors are not endogenous. When the assumption of zero conditional mean of the error term given the regressors is not satisfied, the estimators will be inconsistent. This can be corrected by using instrumental variables estimation to find a variable correlated with wages but not with the error term. Further work is required to test endogeneity and instrumental variables regression should be used if the problem is detected. 
age groups. Card and Lemieux (2001) suggest a two-step estimation procedure to identify both $\sigma_{A}$ and $\sigma_{E}$.

The first stage of the two-step estimation consists of estimating $\sigma_{A}$ from a regression of age-group-specific college wage gaps on age-groupspecific relative supplies of college educated labor, cohort effects, and time effects:

$$
r_{j t}=b_{t-j}+d_{t}-\frac{1}{\sigma_{A}} \ln \left(\frac{C_{j t}}{H_{j t}}\right)+e_{j t}
$$

where $b_{t-j}$ are cohort dummies and $d_{t}$ are time dummies. Supplies $C_{j t}$ and $H_{j t}$ for each age group $j$ in year $t$ are computed by:

$$
s_{j t}=\varphi_{j t}^{s}+\sum_{k} \delta_{j t k}^{s} \hat{\tau}_{t k}^{s}
$$

where $s, s \in\{C, H\}$, denotes the category that the calculation is carried out for, $\varphi$ is the sum of the average weekly hours worked by male workers in the dataset, and $\delta$ contains the sum of the average weekly hours worked by the different education categories, $k$. When $s=H$, $k \in\{$ less than high school, incomplete college $\}$, for $s=C, k \in\{$ higher than college $\}$. Finally, $\hat{\tau}$ is the estimated wage gap between $k$-workers with respect to $s$-workers, and the coefficient is used as a weight for $\delta$. The parameter $\hat{\tau}$ is estimated three times for each year, depending on $k$, and the explanatory variables considered in the model are a seconddegree polynomial for age, a dummy variable for marital status, six economic activity dummies, five regional dummies, and educational level dummies according to $k$. Note that in Equation (11) $\hat{\tau}$ does not depend on age group $j$, however further studies could provide more insight into this issue. Equation (11) attempts to take into account differences in the effective supply of labor by different groups. Card and Lemieux (2001) and Ferreira (2004) adopt a similar procedure. The difference is that Ferreira (2004) is unable to identify college dropouts in order to determine the respective labor efficiency, and therefore they are considered college-educated workers.

In the second stage of the two-step estimation procedure, given an estimate of $1 / \sigma_{A}$, the relative efficiency parameters $\alpha_{j t}$ and $\beta_{j t}$ are computed since equations (4) and (5) are equivalent to estimating: 


$$
\begin{aligned}
& \ln \left(w_{j t}^{H}\right)+\frac{1}{\sigma_{A}} \ln H_{j t}=\ln \left(\theta_{h t} H_{t}^{\rho-\eta} \Psi_{t}\right)+\ln \left(\beta_{j t}\right) \\
& \ln \left(w_{j t}^{C}\right)+\frac{1}{\sigma_{A}} \ln C_{j t}=\ln \left(\theta_{h t} C_{t}^{\rho-\eta} \Psi_{t}\right)+\ln \left(\alpha_{j t}\right)
\end{aligned}
$$

The terms on the left are computed using a first-step estimate of $1 / \sigma_{A}$, while the terms on the right are estimated using a set of time dummies and cohort dummies. Thus, given estimates of $\alpha_{j t}, \beta_{j t}$ and $\eta$, it is possible to construct estimates of aggregate supply of college-educated and high-school-educated labor in each year. According to Card and Lemieux (2001), since the sampling variances of the estimated $r_{j t}$ 's are known, it is straightforward to construct goodness-of-fit tests for the null hypothesis of no specification error, depending on the included effects. Finally, the model could be estimated by weighted least squares, where the dependent variable is the college-high school wage gap for each age group. The weights are the inverse of the sampling variance of the estimated wage gaps. This procedure is used to account for samplegenerated heteroscedasticity, and the estimates of the coefficient errors are corrected for the various problems inherent in the two-stage method.

\section{RESULTS}

Table 1 presents the summary statistics for key variables for individuals from the data used in the analysis. In the eight periods, most of the variables listed are very similar. As expected, average schooling increased from 9.46 years in 2005 to 10.28 years in 2012; growth in schooling as an investment in human capital has been one of Mexico's most impressive achievements $^{3}$. The most significant growth was recorded for the group of high-school-educated workers, which jumped from 35 to $41 \%$ during the period. On the other hand, the small share of college-educated workers grew by just 1 percentage point, from 22 to $23 \%$. The standard deviation for high-school-educated male workers is around 0.5, while for college-graduates it is around 0.4. These large values for standard deviations indicate the possible existence of heteroscedasticity. In addition, we see incipient growth of the average real log hourly wage. 
Table 1. Summary statistics, male workers 25-59 years old

\begin{tabular}{|c|c|c|c|c|}
\hline \multirow{2}{*}{ Variable } & \multicolumn{2}{|c|}{2005} & \multicolumn{2}{|c|}{2006} \\
\hline & Mean & Std. dev. & Mean & Std. dev. \\
\hline Age & 40.103 & 9.110 & 40.026 & 9.135 \\
\hline Years of schooling & 9.463 & 4.875 & 9.518 & 4.864 \\
\hline Real log hourly wage & 3.027 & 0.750 & 3.077 & 0.759 \\
\hline Weekly work hours & 49.691 & 13.132 & 49.594 & 13.009 \\
\hline Primary school & 0.839 & 0.368 & 0.840 & 0.367 \\
\hline Junior high school & 0.607 & 0.489 & 0.618 & 0.486 \\
\hline High school & 0.348 & 0.476 & 0.354 & 0.478 \\
\hline College & 0.215 & 0.411 & 0.213 & 0.409 \\
\hline Postgraduate education & 0.015 & 0.121 & 0.019 & 0.138 \\
\hline \multirow[t]{2}{*}{$\mathrm{N}$} & 40,034 & & 41,217 & \\
\hline & \multicolumn{2}{|c|}{2007} & \multicolumn{2}{|c|}{2008} \\
\hline Age & 40.235 & 9.133 & 40.379 & 9.240 \\
\hline Years of schooling & 9.743 & 4.799 & 9.662 & 4.803 \\
\hline Real log hourly wage & 3.166 & 0.744 & 3.186 & 0.743 \\
\hline Weekly work hours & 49.559 & 12.988 & 49.592 & 13.078 \\
\hline Primary school & 0.858 & 0.349 & 0.854 & 0.353 \\
\hline Junior high school & 0.639 & 0.480 & 0.638 & 0.481 \\
\hline High school & 0.371 & 0.483 & 0.366 & 0.482 \\
\hline College & 0.225 & 0.417 & 0.218 & 0.413 \\
\hline Postgraduate education & 0.017 & 0.130 & 0.018 & 0.132 \\
\hline \multirow[t]{2}{*}{$\mathrm{N}$} & 40,430 & & 40,293 & \\
\hline & \multicolumn{2}{|c|}{2009} & \multicolumn{2}{|c|}{2010} \\
\hline Age & 40.343 & 9.256 & 40.324 & 9.250 \\
\hline Years of schooling & 9.846 & 4.702 & 10.063 & 4.634 \\
\hline Real log hourly wage & 3.190 & 0.725 & 3.196 & 0.710 \\
\hline Weekly hours of work & 49.202 & 13.057 & 49.212 & 12.978 \\
\hline Primary school & 0.871 & 0.335 & 0.881 & 0.323 \\
\hline Junior high school & 0.659 & 0.474 & 0.686 & 0.464 \\
\hline High school & 0.375 & 0.484 & 0.394 & 0.489 \\
\hline College & 0.221 & 0.415 & 0.228 & 0.419 \\
\hline Postgraduate education & 0.019 & 0.138 & 0.019 & 0.136 \\
\hline $\mathrm{N}$ & 38,138 & & 38,416 & \\
\hline
\end{tabular}


Table 1. (continued)

\begin{tabular}{|c|c|c|c|c|}
\hline \multirow{2}{*}{ Variable } & \multicolumn{2}{|c|}{2011} & \multicolumn{2}{|c|}{2012} \\
\hline & Mean & Std. dev. & Mean & Std. dev. \\
\hline Age & 40.397 & 9.259 & 40.579 & 9.307 \\
\hline Years of schooling & 10.047 & 4.594 & 10.281 & 4.530 \\
\hline Real log hourly wage & 3.205 & 0.703 & 3.250 & 0.697 \\
\hline Weekly work hours & 49.390 & 13.080 & 49.556 & 13.009 \\
\hline Primary school & 0.888 & 0.315 & 0.897 & 0.304 \\
\hline Junior high school & 0.688 & 0.463 & 0.716 & 0.451 \\
\hline High school & 0.391 & 0.488 & 0.409 & 0.492 \\
\hline College & 0.224 & 0.417 & 0.234 & 0.424 \\
\hline Postgraduate education & 0.018 & 0.132 & 0.020 & 0.139 \\
\hline $\mathrm{N}$ & 38,897 & & 37,363 & \\
\hline
\end{tabular}

Figure 1 provides the historical proportion of male workers with a college degree in the sample, capturing varying perspectives across individuals and settings. Although Mexico currently has a broad and diverse system of higher education that includes public and private institutions such as universities, technological institutes, technological universities, polytechnic universities, teachers' colleges, research centers, and specialized education centers, the percentage of workers with college degrees is less than 25 .

Each column of Table 2 contains the estimated coefficients of Equation (8) for men aged 25-59. Following Card and Lemieux (2001) and Ferreira (2004), only men with a high school diploma and men with a college degree are considered. The random effect procedure is appropriate according to the Breusch-Pagan Lagrange multiplier test, suggesting its use instead of pooled regression. In addition, F- and Hausman test results favor random effects over fixed effects ${ }^{4}$. The models for each year include a second-degree polynomial for age, marital status, six economic activity

4. For all eight years the associated p-values from the Breusch-Pagan Lagrange multiplier test, distributed as $\chi_{(1)}^{2}$, are less than 0.01 . In the case of the F-test, a p-value $<0.01$ is obtained for all eight years. Finally, a p-value $>0.95$ in all years is obtained by the Hausman test. 
Figure 1. Proportion of workers with only a high school diploma and those with a college degree

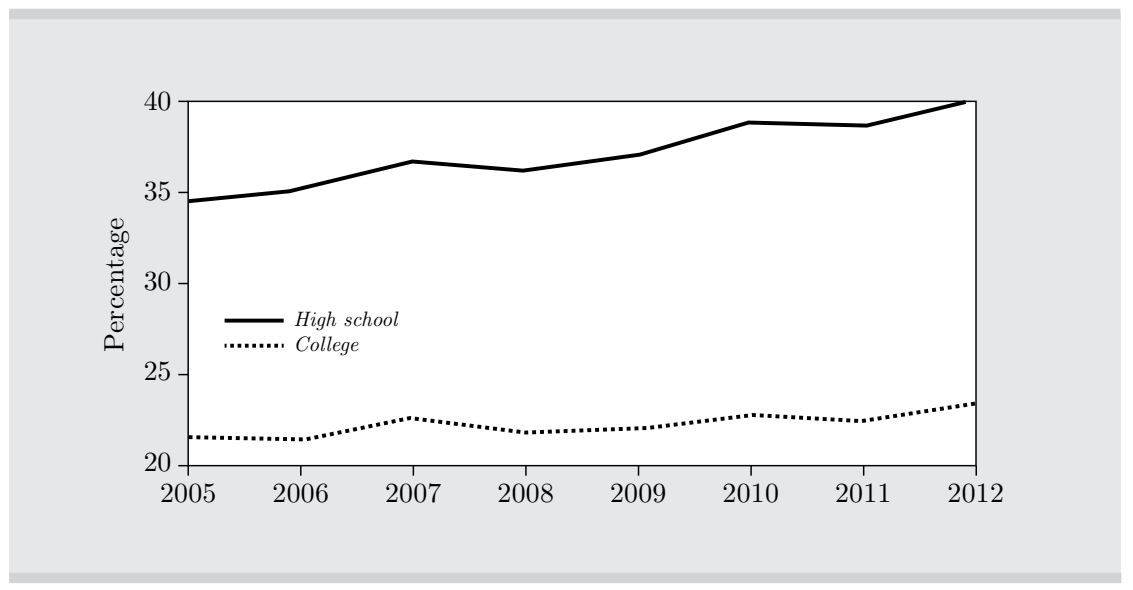

Source: Table 1.

dummies, and five regional dummies ${ }^{5}$. The results are in agreement with previous studies (Hanson, 2003 or Varela, 2010); as is well known, the log mean wage difference between college and high school workers is around 0.5. Tables A1 and A2 in the appendix show alternative specifications that include, separately, controls for type of occupation and employment position. Table A3 includes both types of controls simultaneously. The wage-gap differences across different models are significant: about 0.4 and 0.5. In principle, all four specifications capture the strong effect of having a college degree on wages, so the explanatory variables shown in Table 1 will be those used in the subsequent models.

The estimated college premium remains almost constant over time; Table 3 presents the estimated college wage premiums for five-year age groups using Equation (9). All estimations are based on the mean log average real hourly wage between men with a college degree and those with only a high school diploma. They are estimated in separate regression models for each cohort in each year, including the age term and its quadratic, marital status, economic activity dummies, and regional dummies.

5. The economic activity dummies were selected based on the ENOE questionnaire, where a1 = Construction; a2 = Manufacturing; a3 = Trade; a $4=$ Services; a $5=$ Other activities and a $6=$ Agricultural. The regionalization corresponds to that used by the Presidency since 2002, where R1= Baja California, Baja California Sur, Sonora, and Sinaloa; R2 = Chihuahua, Coahuila, Durango, Tamaulipas, and Nuevo León; R3 = Aguascalientes, Colima, Guanajuato, Jalisco, Michoacán, Nayarit, Querétaro, San Luis Potosí, and Zacatecas; R4 = Distrito Federal, Hidalgo, México, Morelos, Puebla, and Tlaxcala; and R5 = Campeche, Chiapas, Guerrero, Oaxaca, Quintana Roo, Tabasco, Veracruz, and Yucatán. 


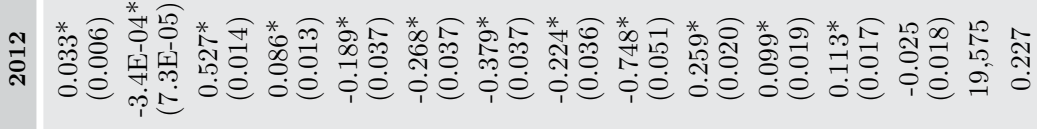

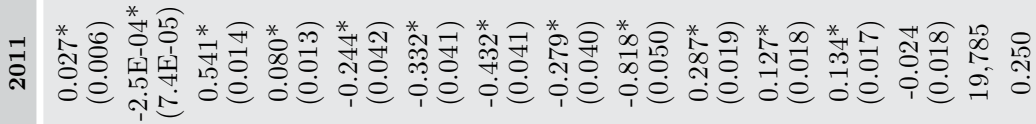

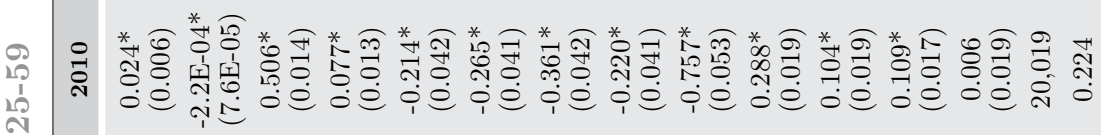

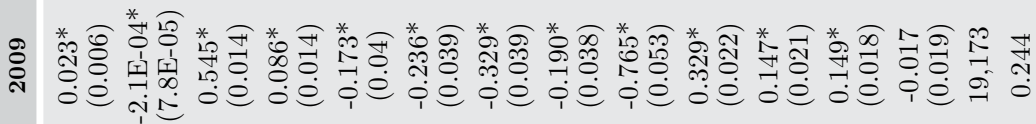

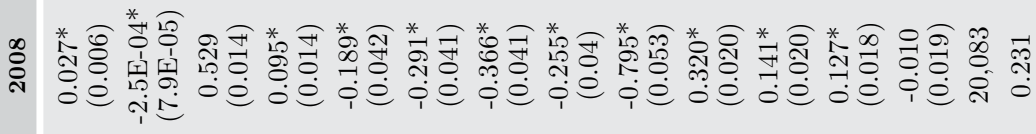

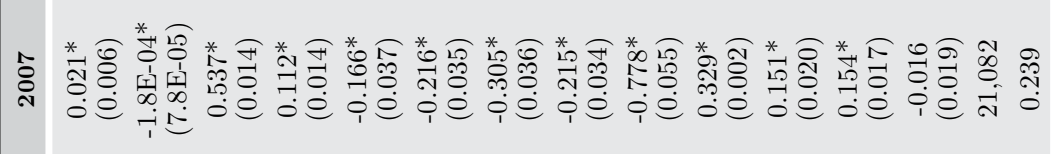

กั่

동

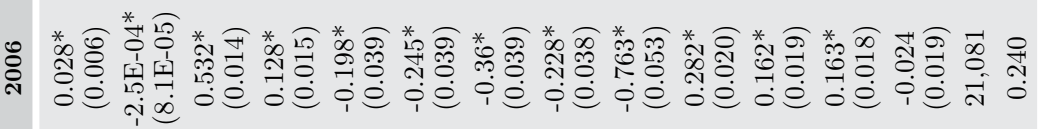

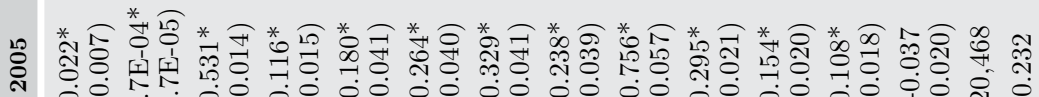


According to standard human capital theory, this differential increases steadily with age, but conventional models ignore differences in the age distribution of educational attainment. Unlike the results found in Table 2, the decomposition of age groups reveals the difference in wages between younger and older male workers. In general, the results support the standard statement of Mincer's (1974) equation: Older people have greater returns. Another important result is that by substituting age and its square for five-year age group dummies in a model such as in Table 2, it is possible to perform the Wald test. The results ${ }^{6}$ indicate that the estimated coefficients of younger men (aged 25-29) in relation to older workers (aged 45-49, 50-54, and 55-59) are statistically different. In other words, it is necessary to dig deeper into the phenomenon by considering its relative supplies.

Figure 2 plots the college-high school wage gap for younger and older groups over the period analyzed. The overall patterns for the college premium for men aged 25-29 and 45-49 are very similar across years, but it appears that the evolution of the college premium for younger and older workers has tended to diverge since the financial and economic crisis of 2008. Once again, these results underscore the importance of studying differentials in the college premium among cohort groups. By examining the wage gaps for older workers aged 50-54 and 55-59, it is possible to infer that the difference has remained practically constant, with slight decreases toward the end of 2012. The employment stability earned by members of this age group may be a potential explanatory factor.

The more relevant change revealed by Figure 2 is the growing trend in the wage differential in the group of male workers aged 45-49. Conversely, the college premium among younger workers seems to have declined; it is important to highlight the fact that the financial crisis has had a particularly adverse effect on younger workers in Mexico (Villarreal, 2010). The importance of this lies in the fact that on the one hand, in the short term younger people have an incentive not to continue to higher levels of education. On the other hand, if young people decide to invest in higher levels of education, the main effect on the college premium will be observed in the long term.

To understand this change, we need to be aware not only of the gap between workers with the same education and different ages, but also of 
Figure 2. College-high school wage differentials by age group
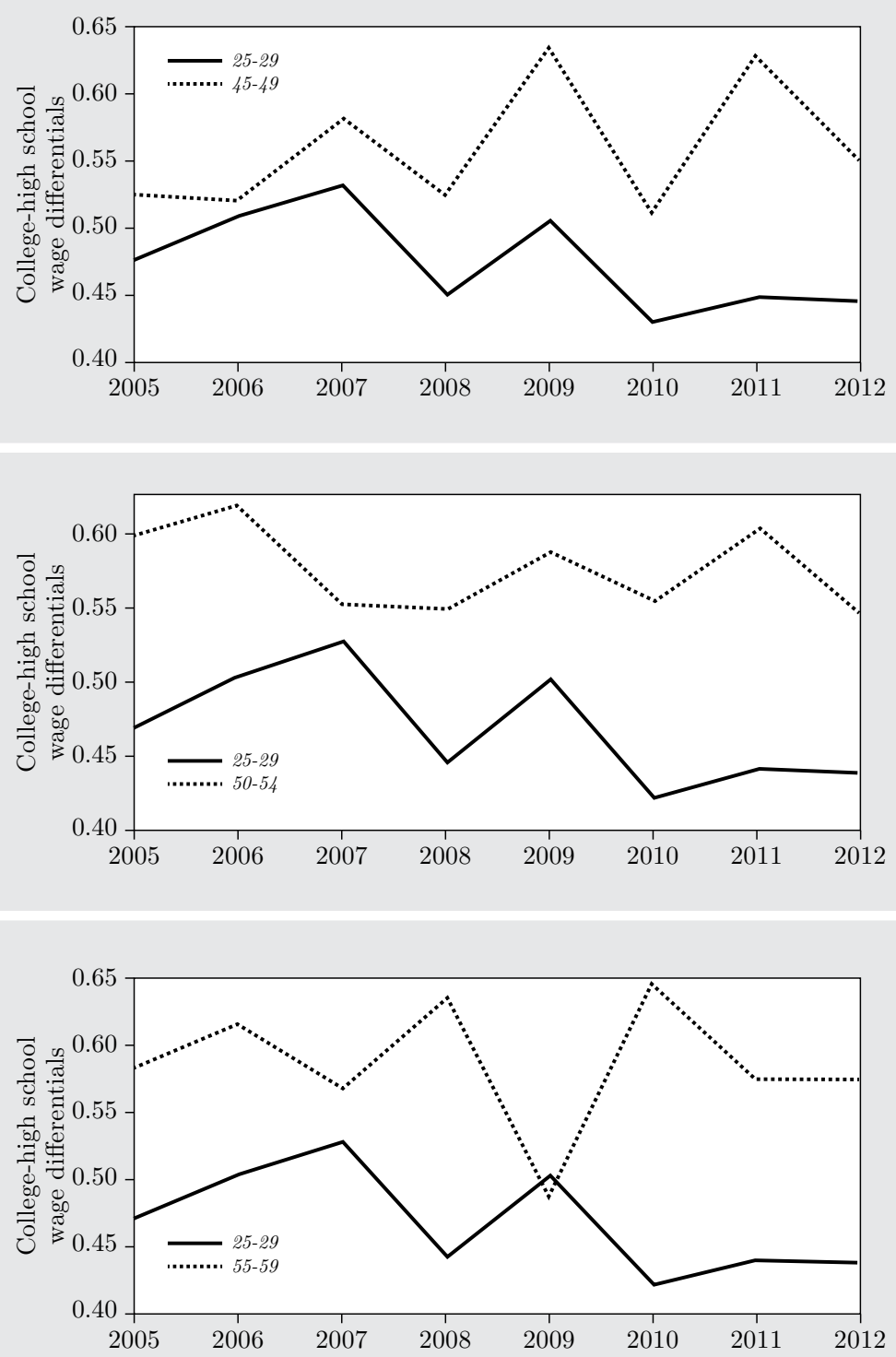
Table 3. Estimated college-high school wage differentials by age groups

\begin{tabular}{lccccccc}
\hline Year/age & $\mathbf{2 5 - 2 9}$ & $\mathbf{3 0 - 3 4}$ & $\mathbf{3 5 - 3 9}$ & $\mathbf{4 0 - 4 4}$ & $\mathbf{4 5 - 4 9}$ & $\mathbf{5 0 - 5 4}$ & $\mathbf{5 5 - 5 9}$ \\
\multirow{2}{*}{2005} & 0.470 & 0.530 & 0.534 & 0.528 & 0.521 & 0.599 & 0.584 \\
& $(0.032)$ & $(0.032)$ & $(0.032)$ & $(0.034)$ & $(0.038)$ & $(0.047)$ & $(0.074)$ \\
2006 & 0.504 & 0.469 & 0.598 & 0.508 & 0.517 & 0.619 & 0.613 \\
& $(0.030)$ & $(0.031)$ & $(0.030)$ & $(0.031)$ & $(0.039)$ & $(0.048)$ & $(0.070)$ \\
2007 & 0.528 & 0.518 & 0.531 & 0.515 & 0.579 & 0.552 & 0.568 \\
& $(0.030)$ & $(0.032)$ & $(0.030)$ & $(0.032)$ & $(0.035)$ & $(0.046)$ & $(0.061)$ \\
2008 & 0.444 & 0.526 & 0.541 & 0.566 & 0.521 & 0.549 & 0.634 \\
& $(0.031)$ & $(0.033)$ & $(0.033)$ & $(0.032)$ & $(0.036)$ & $(0.044)$ & $(0.062)$ \\
2009 & 0.501 & 0.574 & 0.491 & 0.528 & 0.633 & 0.588 & 0.488 \\
& $(0.034)$ & $(0.029)$ & $(0.032)$ & $(0.035)$ & $(0.037)$ & $(0.044)$ & $(0.065)$ \\
2010 & 0.422 & 0.501 & 0.517 & 0.502 & 0.506 & 0.554 & 0.645 \\
& $(0.030)$ & $(0.031)$ & $(0.031)$ & $(0.034)$ & $(0.034)$ & $(0.044)$ & $(0.067)$ \\
2011 & 0.441 & 0.500 & 0.545 & 0.516 & 0.627 & 0.602 & 0.575 \\
& $(0.029)$ & $(0.030)$ & $(0.032)$ & $(0.033)$ & $(0.035)$ & $(0.044)$ & $(0.059)$ \\
2012 & 0.438 & 0.506 & 0.561 & 0.594 & 0.546 & 0.545 & 0.573 \\
& $(0.030)$ & $(0.031)$ & $(0.031)$ & $(0.033)$ & $(0.039)$ & $(0.042)$ & $(0.056)$
\end{tabular}

Source: Own calculations using ENOE data from Q1 2005 to Q4 2012.

Note: Robust standard errors in parentheses.

the composition of the relative supplies. Using Equation $(11)^{7}$, we can compute the average weekly hours worked by men aged 25-59 with any level of education; the results are contained in Table 4. According to the notation, $C_{j t}$ corresponds to the number of hours per week worked by college graduates by age group $j$ in year $t$ including postgraduate workers, weighted by their wage gap. Likewise, $H_{j t}$ is the total number of weekly hours worked by the labor force with incomplete college or less education, weighted by wage differentials.

The estimation of the relative supply of workers with a college degree shows an important growth trend in young workers, with an increase from 0.3 to 0.4 in less than a decade. This ratio may be explained because returns to education in Mexico are substantial and higher than those estimated for developed countries (see Psacharopoulos, et al. (1996), Psacharopoulos and Patrinos (2004), or Canton (2007) for details), whereas the natural laws of supply and demand would typically

7. The procedure is to compute Equation (11) estimating $\hat{\tau}_{t k}^{s}$ in separate regressions depending on $s$. A total of 24 panel data models are used to construct Table 4, taking into account differences in the effective supply of skilled and low-skilled workers. The results are not reported but are available from the author upon request. 
Table 4. Relative college labor supply by age group

\begin{tabular}{|c|c|c|c|c|c|c|c|}
\hline \multirow{2}{*}{ Year/age } & $25-29$ & $30-34$ & $35-39$ & $40-44$ & $45-49$ & $50-54$ & $55-59$ \\
\hline & \multicolumn{7}{|c|}{ College } \\
\hline 2005 & 59,657 & 50,169 & 52,764 & 41,174 & 45,751 & 28,685 & 17,697 \\
\hline 2006 & 60,193 & 55,440 & 55,785 & 50,308 & 47,343 & 32,394 & 17,109 \\
\hline 2007 & 62,544 & 51,116 & 56,128 & 55,115 & 45,513 & 30,686 & 19,388 \\
\hline 2008 & 62,478 & 48,750 & 49,749 & 52,419 & 49,444 & 33,686 & 21,281 \\
\hline 2009 & 58,072 & 51,055 & 53,408 & 49,704 & 46,495 & 34,073 & 22,090 \\
\hline 2010 & 60,201 & 49,328 & 50,085 & 51,993 & 48,848 & 34,541 & 20,516 \\
\hline 2011 & 63,335 & 49,672 & 49,258 & 50,424 & 45,126 & 36,840 & 23,187 \\
\hline \multirow[t]{2}{*}{2012} & 64,801 & 50,613 & 49,830 & 49,923 & 44,150 & 38,609 & 22,775 \\
\hline & \multicolumn{7}{|c|}{ High school } \\
\hline 2005 & 186,224 & 169,608 & 167,428 & 155,711 & 126,039 & 103,986 & 77,399 \\
\hline 2006 & 184,196 & 173,038 & 180,254 & 159,046 & 129,565 & 101,655 & 77,633 \\
\hline 2007 & 177,967 & 169,256 & 169,789 & 163,969 & 132,831 & 107,536 & 78,591 \\
\hline 2008 & 179,068 & 164,582 & 172,613 & 159,286 & 131,924 & 112,373 & 78,108 \\
\hline 2009 & 173,832 & 152,572 & 166,466 & 153,568 & 131,646 & 109,908 & 78,071 \\
\hline 2010 & 171,487 & 150,761 & 166,517 & 155,081 & 133,894 & 107,476 & 76,403 \\
\hline 2011 & 176,408 & 158,454 & 175,127 & 162,847 & 138,741 & 113,022 & 82,016 \\
\hline \multirow[t]{2}{*}{2012} & 162,888 & 139,709 & 165,205 & 159,786 & 134,524 & 110,889 & 81,603 \\
\hline & \multicolumn{7}{|c|}{ Relative supply } \\
\hline 2005 & 0.320 & 0.296 & 0.315 & 0.264 & 0.363 & 0.276 & 0.229 \\
\hline 2006 & 0.327 & 0.320 & 0.309 & 0.316 & 0.365 & 0.319 & 0.220 \\
\hline 2007 & 0.351 & 0.302 & 0.331 & 0.336 & 0.343 & 0.285 & 0.247 \\
\hline 2008 & 0.349 & 0.296 & 0.288 & 0.329 & 0.375 & 0.300 & 0.272 \\
\hline 2009 & 0.334 & 0.335 & 0.321 & 0.324 & 0.353 & 0.310 & 0.283 \\
\hline 2010 & 0.351 & 0.327 & 0.301 & 0.335 & 0.365 & 0.321 & 0.269 \\
\hline 2011 & 0.359 & 0.313 & 0.281 & 0.310 & 0.325 & 0.326 & 0.283 \\
\hline 2012 & 0.398 & 0.362 & 0.302 & 0.312 & 0.328 & 0.348 & 0.279 \\
\hline
\end{tabular}

yield a decrease in the college premium. Even more notably, the trend for the estimated supplies of older workers has a differentiated effect on the college premium. Individuals aged 45-49 recorded a decrease of around 4\%, while conversely, individuals aged 50-54 and 55-59 increased their participation. In general, the results contained in tables 3 and 4 show a surprisingly mixed effect on wage differentials and relative supplies. 
Figure 3 shows the behavior of relative supplies for each age group of interest. In all cases, with the exception of specific years for workers aged 45-49, the relative supply of the younger group is higher than the relative supply of older groups. One possible reason for this large difference is strongly suggested by the weighting parameter $\hat{\tau}$ in Equation (11). As previous work (Zepeda and Ghiara, 1999, Zamudio, 2001, Cañonero and Werner, 2002, and Hanson, 2003) has suggested, the recent increase in inequality in the income distribution is largely due to education. Thus, after trade liberalization occurred, the average relative wage of unskilled workers decreased and then, the effective supply may have been reduced for older cohorts.

Within this framework, the increase in the college-high school wage gap in workers aged 45-49 is attributable to steadily rising relative demand for college-educated labor, coupled with a dramatic slowdown in the rate of growth of the relative supply of college-educated workers. Card and Lemieux (2001) and Ferreira (2004) find similar behavior for groups of younger workers, but in the case of Mexico, younger workers are the segment of the population that is most affected, with unemployment rates twice as high as those of older adults. Furthermore, better-educated professionals have the highest unemployment rate (Villarreal, 2010).

The final step is to estimate two parameters of interest: the elasticity of substitution between the two education groups and the elasticity of substitution between different age groups. Using Equation (7) I establish the cohort born in 1956-1960 (aged 45-49) as the control group, hence the results presented correspond to differences with regard to older workers. The model presented in Table 5 suggests that a $1 \%$ increase in the relative supply of college labor causes a decrease of 0.33 percentage points in the college-high school wage differential, in the absence of non-neutral technology changes. Also, a 1\% increase in the age-specific relative supply of college labor decreases the college premium by 0.6 percentage points, for that particular age group.

The empirical evidence provides an estimated elasticity of substitution between different age groups of around 1.7, while the parameter for the two education groups is about 3 . We note that this specification does not seem to capture the annual wage gap (year effect) that would have, on average, increased in the absence of the age/cohort productivity factor and changes in supply according to educational level. In fact, the coefficients are not statistically different from 0 because the yearly dummies cannot capture technology shocks, which would require a long time-series sample and five-year interval dummies. 
Figure 3. Relative college labor supply by age group
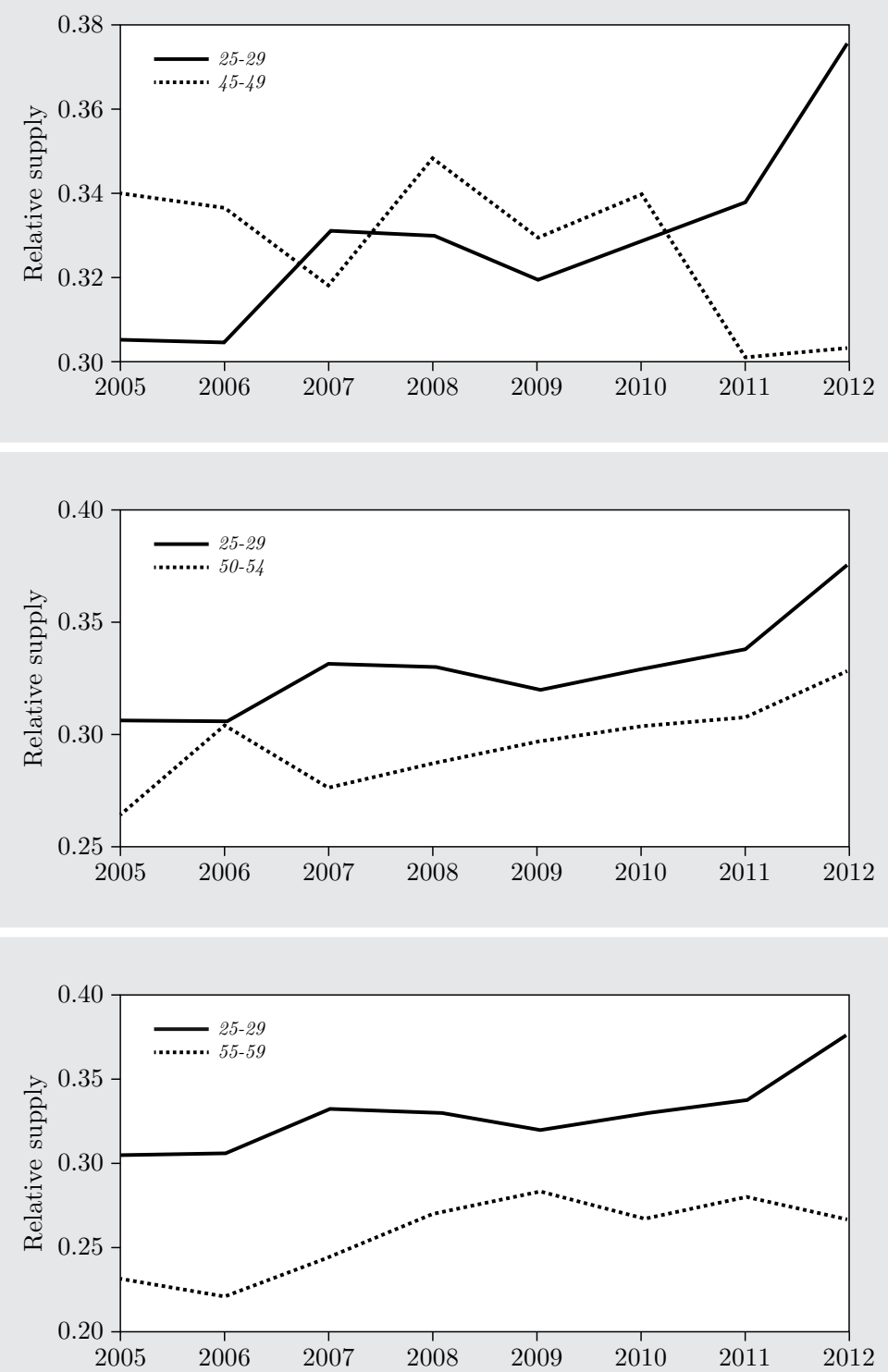
Table 5 Estimated college-high school wage gap by cohort and year

\begin{tabular}{|c|c|c|}
\hline Age-specific relative supply & $-0.601^{*}$ & $(0.100)$ \\
\hline Aggregate supply index & $-0.332^{*}$ & $(0.121)$ \\
\hline \multicolumn{3}{|l|}{ Age effect } \\
\hline $25-29$ & $-0.121^{*}$ & $(0.012)$ \\
\hline $30-34$ & $-0.090^{*}$ & $(0.011)$ \\
\hline $35-39$ & $-0.063^{*}$ & $(0.009)$ \\
\hline $40-44$ & $-0.050^{*}$ & $(0.007)$ \\
\hline $50-54$ & 0.013 & $(0.008)$ \\
\hline $55-59$ & $0.026^{*}$ & $(0.013)$ \\
\hline \multicolumn{3}{|l|}{ Cohort effect } \\
\hline $1946-1950$ & $-0.050^{*}$ & $(0.010)$ \\
\hline $1951-1955$ & $-2 \mathrm{E}-04$ & $(0.009)$ \\
\hline $1961-1965$ & $0.015^{*}$ & $(0.006)$ \\
\hline $1966-1970$ & $0.019^{*}$ & $(0.006)$ \\
\hline $1971-1975$ & $0.024^{*}$ & $(0.007)$ \\
\hline $1976-1980$ & $0.032^{*}$ & $(0.008)$ \\
\hline $1981-1985$ & $0.029^{*}$ & $(0.009)$ \\
\hline $1986-1990$ & 0.021 & $(0.012)$ \\
\hline \multicolumn{3}{|l|}{ Year effect dummies } \\
\hline 2006 & -0.010 & $(0.007)$ \\
\hline 2007 & 0.0010 & $(0.007)$ \\
\hline 2008 & -0.010 & $(0.007)$ \\
\hline 2009 & -0.003 & $(0.008)$ \\
\hline 2010 & -0.003 & $(0.007)$ \\
\hline 2010 & $-0.024^{*}$ & $(0.008)$ \\
\hline 2012 & $-0.121^{*}$ & $(0.010)$ \\
\hline
\end{tabular}

As a general rule, the elasticity of substitution captures the percentage change in relative demand for the two factors due to the change in relative factor prices at constant output. Also, the parameter of substitution between college and high school labor influences the impact of schooling on the education wage premium. In the traditional sense, the reduction is larger if the elasticity is low; i.e., they are far from perfect substitutes. 
Similar studies for U.S, the U.K. and Canada (Card and Lemieux, 2001) and for Brazil (Ferreira, 2004) suggest that the elasticity of substitution between different age groups is 4.4. At the same time, the elasticity of substitution between college and high school labor types is about 2.5, and less than 2 in the case of Brazil. Nevertheless, these studies have analyzed long time-series data sets: 1959-1995 for the U.S., the U.K. and Canada, and 1976-1998 for Brazil. In marked contrast, this study of Mexico is focused on the short term, taking advantage of quarterly datasets. The results in Table 5 indicate that the two education groups are more easily substituted in Mexico than in other countries. In contrast, the substitution of workers between different age groups seems to be more complicated, based on the small estimated value for the elasticity of substitution.

This finding could be explained by the structural change occurring in Mexico's labor market. According to the literature review, empirical studies for Mexico have concluded that the wage gap between the two education groups has tended to widen with trade liberalization. The intuition behind previous studies is that employers reward skilled workers with an important college wage premium, making them hard to substitute. However, the combination in recent years of a high unemployment rate for skilled workers, slow economic growth, and the negative effects of the financial crisis could potentially explain this result.

\section{CONCLUDing ReMARKS}

This paper has introduced the first evidence in Mexico of the estimated evolution of the college wage gap by age groups, controlling for the relative supply of college graduate workers. Following the econometric methodology proposed by Card and Lemieux (2001) and using rotating panel data from 2005 to 2012, I present the partial elasticity of substitution between college and high school workers and across age groups. The results of the estimation indicate the existence of a large elasticity substitution (around 3) between male workers with different levels of education, which could mean that college- and high-school-educated workers are considered easily substitutable by employers. Furthermore, the small value of the estimated parameter (around 1.7) between the two education groups suggests that younger and older workers are viewed as different by employers and they are far from perfect substitutes. This result is very important because it suggests that in the current Mexican 
labor market it is easier to substitute skilled workers with unskilled workers rather than replace older workers with a younger labor force.

Overall, the model presents a negative and significant effect on the college premium for cohort variations in relative supply. This study highlights a decreasing trend in the college wage gap for younger workers (aged 25-29) combined with an increasing trend in the wage gap for older workers (aged 45-49). On the other hand, the behavior of the college premium for the oldest groups (aged 50-54 and 55-59) describes a constant trend in the wage gap.

The overall patterns for the college premium for men aged 25-29 and 45-49 are very similar across years but it appears that the evolution of the college premium for younger and older workers has tended to diverge after the financial and economic crisis of 2008. This underscores the need for wage gap studies in Mexico to consider the specific composition of workers by age group. According to this model, valid in a scenario of perfectly competitive equilibrium, the recent downward trend in the college premium for younger men depends mainly on the age effect. Although the results imply imperfect substitution between skilled and unskilled labor, it seems that in the case of Mexico, in contrast with the U.S., the U.K, Canada or Brazil, there is a small elasticity of substitution between the two age groups. An important implication of this finding is that, because of the aging of the population and increased levels of schooling, younger, educated workers are the segment of the population that is most affected.

The demographic and schooling transformation now underway in Mexico has the potential to both help and hinder its overall economic development agenda. Modifications of Mexico's Federal Labor Law enacted in 2012 brought important changes from an employer's perspective. One of the most interesting is the expansion of the types of employment relationships that are legally allowed. In addition to the already existing contracts for an indefinite term or a specific project, the reform introduced the seasonal employment category, which allows short-term employment to cover the need for additional workforce requirements during seasonal peaks, and the temporary employment contract, which permits short-term employment to cover immediate needs. In principle, the new recruitment scheme could have a positive impact on highly educated younger workers since seasonal or temporary employment could provide them with jobs and enable them to begin gaining experience quickly. 
Finally, the results imply not only imperfect substitution between older and younger men but also between skilled and unskilled men. Future studies could include more than two categories of educated workers, including for example those with incomplete high school, incomplete college, and advanced degrees, as well as an extension for women in labor markets, controlling for self-selection. 


\section{REFERENCES}

Airola, J. and C. Juhun (2008), "Wage inequality in post-reform Mexico," Journal of Income Distribution 17(1): 110-34.

Ampudia, N. (2007), "Política monetaria, restricción crediticia y empleo," in Mantéy, M. and N. Levy, eds., Políticas macroeconómicas para paises en desarrollo. Mexico: Miguel Ángel Porrúa-UNAM.

Becker, G. (1965), "A theory of the allocation of time," The Economic Journal 75(299): 493-517.

Bia, M., R. Leombruni, and P. Messe (2009), "Young in-old out: A new evaluation based on generalized propensity score," LABORatorio R. Revelli, Working Paper No. 93.

Cañonero, G. and A. Werner (2002), "Salarios relativos y liberación del comercio en México," El Trimestre Económico 69(273): 123-42.

Canton, E. (2007), "Social returns to education: Macro-evidence," De Economist 155(4): 449-68.

Card, D. and T. Lemieux (2001), "Can falling supply explain the rising return to college for younger men? A cohort-based analysis," Quarterly Journal of Economics 116(2): 705-46.

Chiquiar, D. (2008), "Globalization, regional wage differentials and the StolperSamuelson theorem: Evidence from Mexico," Journal of International Economics 74(1): 70-93.

Cragg, M. and M. Epelbaum (1996), "Why has wage dispersion grown in Mexico? Is it the incidence of reforms or the growing demand for skills?" Journal of Development Economics 51(1): 99-116.

Ferreira, S. (2004), "The provision of education and its impacts on college premium in Brazil," Revista Brasileira de Economia 58(2): 211-33.

Gutiérrez, R. (2009). "La recesión y la medición de la tasa de desempleo de México ante una eventual reforma laboral," Economía, Teoría y Práctica 31: 43-72.

Hairault, J., A. Chéron, and F. Langot (2007), "Job creation and job destruction over the life cycle: The older workers in the spotlight," IZA Discussion Paper No. 2597.

Hanson, G. (2003), "What has happened to wages in Mexico since NAFTA? Implications for hemispheric free trade," NBER Working Paper 9563.

Hanson, G. and A. Harrison (1995), "Trade, technology and wage inequality," NBER Working Paper 5110.

Hanson, G. and A. Harrison (1999), "Who gains from trade reform? Some remaining puzles," Journal of Development Economics 59(1): 125-54.

Hernández, E. (2000), Empleo y necesidades de capacitación en mercados regionales de trabajo en México. Mexico: Secretaría del Trabajo y Previsión Social.

Huesca, L. (2004), "La rentabilidad de la escolaridad en los hogares asalariados en México durante 1984-2000," Problemas del Desarrollo 35(138): 125-254. 
Islas, A. and W. Cortez (2011), "How relevant is monetary policy to explain Mexican unemployment fluctuations?" MPRRA Paper No. 30027.

Kalwij, A., A. Kapteyn, and K. Vos (2010), "Retirement of older workers and employment of the young," De Economist 158(4): 341-59.

Katz, L. and K. Murphy (1992), "Changes in relative wages, 1963-1987: Supply and demand factors," Quarterly Journal of Economics 107(1): 35-78.

López, G. (2006), "Mexico: Two decades of the evolution of education and inequality," World Bank Policy Research Working Paper 3919.

Meza, L. (1999), "Cambios en la estructura salarial de México en el período 1988-1993 y el aumento en el rendimiento de la educación superior," El Trimestre Económico 66 (262): 189-226.

Mincer, J. (1974), Schooling, experience and earnings. New York: National Bureau of Economic Research.

Prskawetz, A., T. Tsachev, and V. Veliov (2012), "Optimal education in an agestructured model under changing labor demand and supply," Macroeconomic Dynamics 16(2): 159-83.

Psacharopoulos, G. and H. Patrinos (2004), "Returns to investment in education: A further update," Education Economics 12(2): 111-34.

Psacharopoulos, G., E. Velez, A. Panagides, and H. Yang (1996), "Returns to education during economic boom and recession: Mexico, 1984, 1989 and 1992," Education Economics 4(3): 219-30.

Robertson, R. (2004), "Relative prices and wage inequality: Evidence from Mexico," Journal of International Economics 64(2): 387-409.

Rodríguez-Oreggia, E. (2009), "La dinámica comparativa del sector informal en México: Temas actuales de política económica," in I. Soloaga, ed., Sobre México. Mexico: UPAEP.

Roger, M. and M. Wasmer (2009), "Heterogeneity matters: Labor productivity differentiated by age and skills," Paris School of Economics Working Paper No. 2009-51.

Rones, P. (1983), "Labor market problems of older workers," Monthly Labor Review May: 1-12.

Tello, C. and R. Ramos (2012), "Wage inequality and economic growth in Mexican regions," Investigaciones Regionales 24: 115-52.

Varela, R., et al. (2010), "Determinantes de los ingresos salariales en México: Una perspectiva de capital humano," Región y Sociedad 22(49): 117-42.

Villarreal, M. (2010), The Mexican economy after the global crisis. Mexico: UNT Libraries Government Documents Department.

Zamudio, A. (2001), "La escolaridad y la distribución condicional del ingreso: Una aplicación de regresión cuantil," El Trimestre Económico 68(269): 39-70.

Zepeda, E. and R. Ghiara (1999), "Determinación del salario y capital humano en México: 1987-1993," Economía, Sociedad y Territorio 2(5): 67-116. 


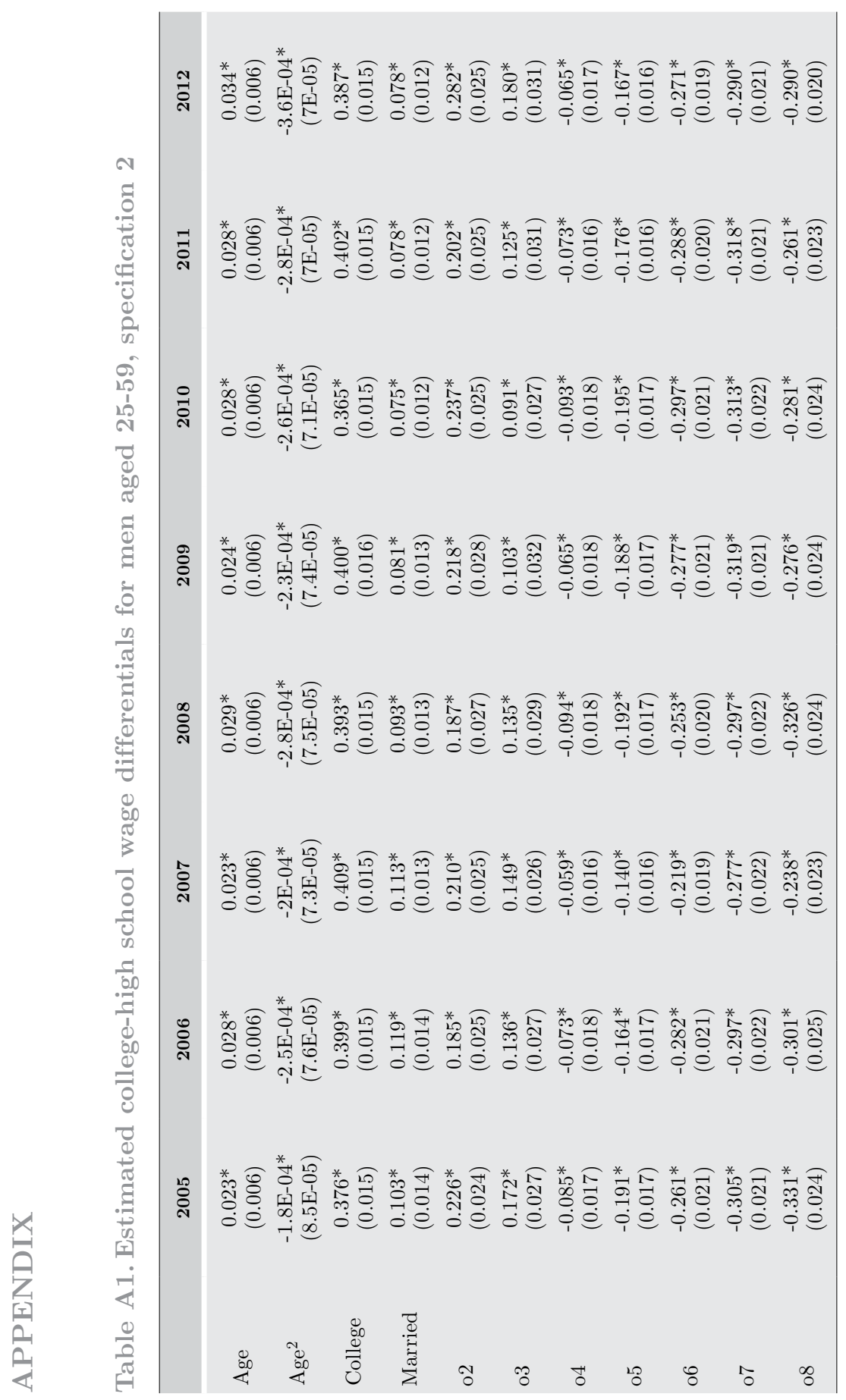




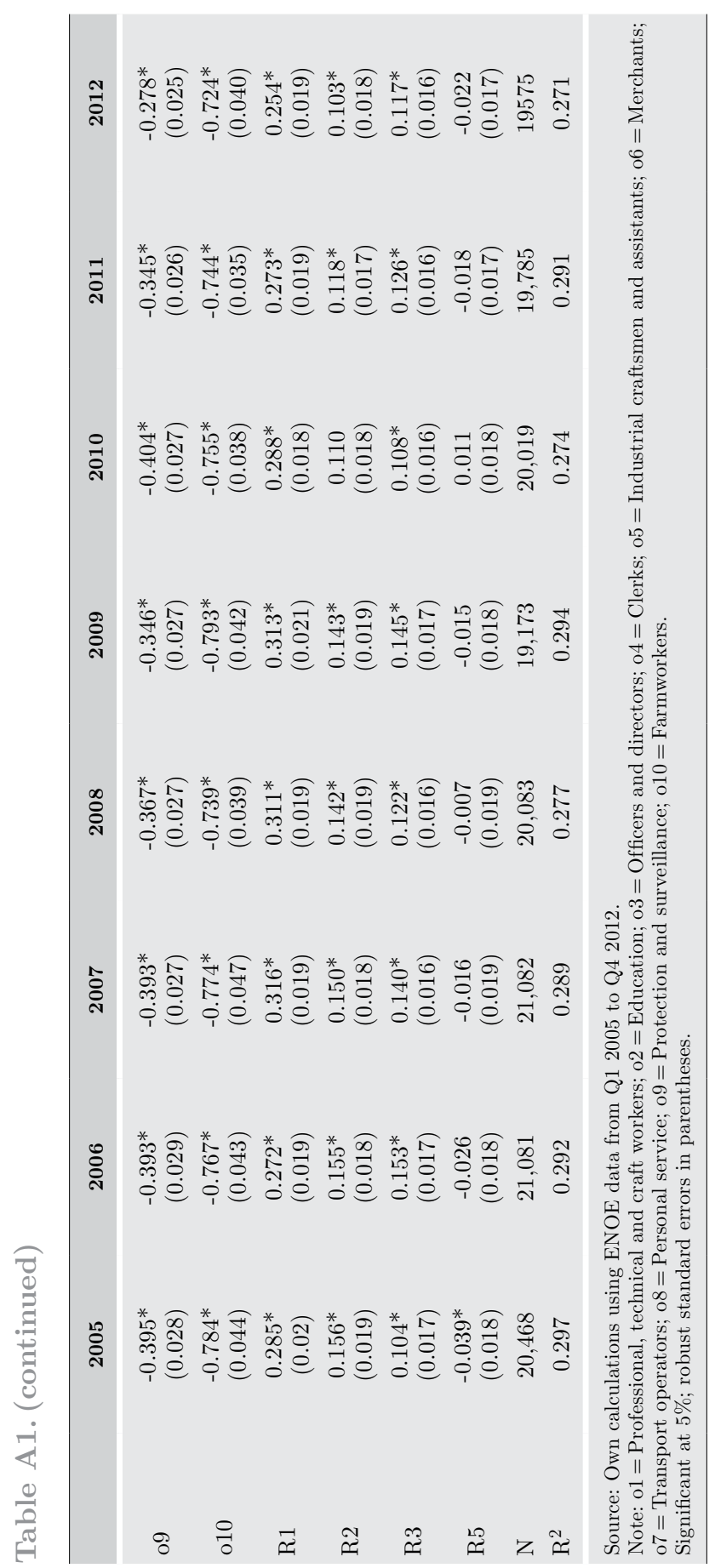




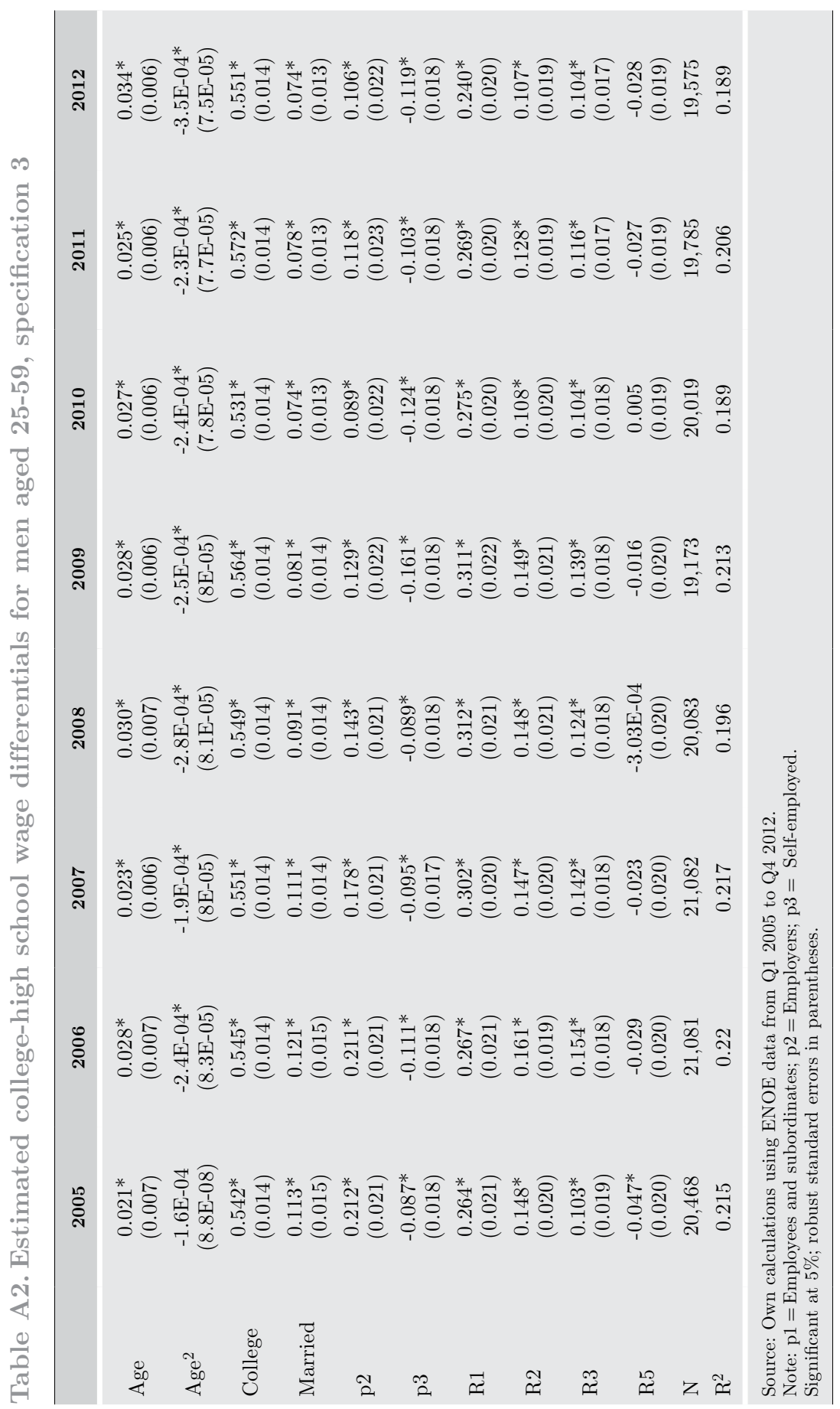




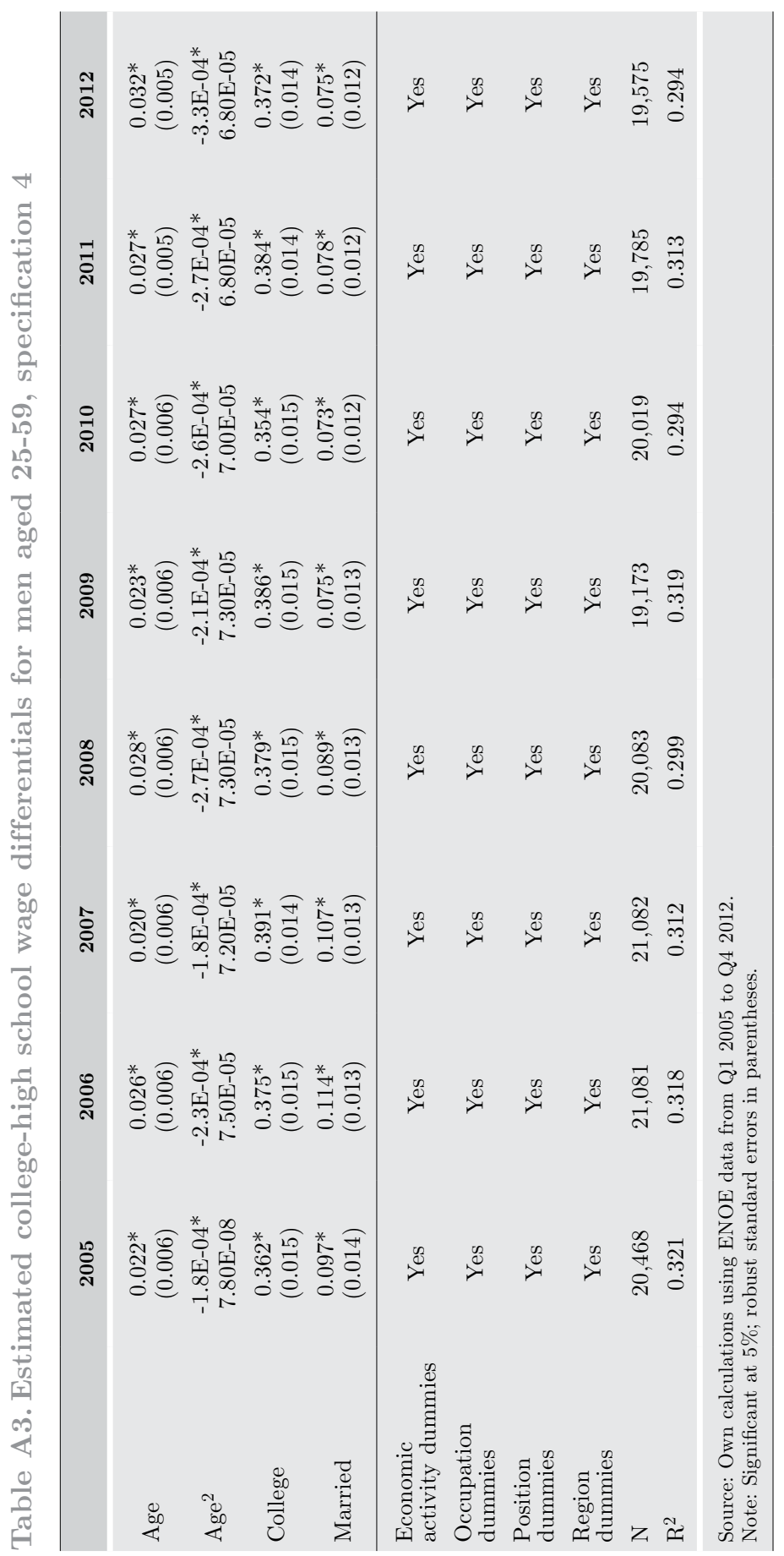

